\title{
High School EFL Teachers' Perception of the Use of Pictures in Pre-Reading Stage
}

\author{
Nguyen Thi Yen Phuong ${ }^{1}$, Nguyen Huynh Trang ${ }^{2}$ \\ ${ }^{1}$ Can Tho University, Vietnam \\ ${ }^{2}$ University of Economics Ho Chi Minh City, Vietnam
}

\begin{abstract}
This descriptive study aims to investigate EFL teachers' perceptions toward the use of pictures in pre-reading stage as well as the role and the possible difficulties of using picture in pre-reading stage that they may gain. The current study adopted both quantitative and qualitative methods to collect the data via questionnaire and semi-structured interviews with the participation of 30 teachers in different high schools in the Mekong Delta, Vietnam and six out of the teachers were invited to participate in the interviews. There are some main following findings. First, EFL teachers highly appreciated about the role of pictures in pre-reading stage. Second, the participants revealed there were some possible difficulties that prevent English teachers from using pictures in pre-reading stage.
\end{abstract}

Keywords - Pre-reading, pictures, pictures' role, EFL teachers, possible difficulties.

\section{INTRODUCTION}

Reading allows students to gain sufficient exposure to the target language as well as essential linguistic input in order to improve their language skills (Erten \& Razi, 2003). Since reading is a process, it begins with looking at the representation of the language surface and concludes with specific thoughts or meanings concerning the messages intended by the writer. Understanding reading materials, according to Jin, Chen, and Wang (2019), entails transferring the author's main idea of the text to the reader's brain. Reading in English, on the other hand, is a daunting and challenging undertaking for most students, especially those who study English as a foreign language (EFL). As a result, learning to read needs time, effort, and a great deal of practice and EFL teachers should have effective ways in teaching reading skill, rather than just supplying students to read the text, answer the questions or explain its purpose. Azizifar et al. (2015) shows that the use of pre-reading activities can enhance the level of students' reading comprehension. These activities enable them to express themselves freely on a subject relevant to the given text before reading in class. By applying pre-reading activities, the students' schemata can be activated and they can have better comprehension in reading written text. Among various techniques, pictures are considered one of the ways used in pre-reading activities (Osei et al., 2016). It can be inferred that using pictures in pre-reading activities can help students internalize the text by relating their background knowledge to the given text.

In Vietnam, Ministry of Education and Training (MoET) launched the National Foreign Languages Project (VNFLP) to improve the quality of teaching and learning foreign languages, particularly English which is considered the most favorable language in schools. The project aims to provide more opportunities for students to practice all four skills of language in meaningful contexts. Teaching reading comprehension is included in the curriculum and help students develop essential skills of reading such as skimming and scanning and enhance strategies, i.e. metacognitive or affective strategies (MOET, 2018). Nevertheless, since reading instruction is mostly based on traditional lecturing, students had minimal exposure to information-processing strategies which makes this skill be the most challenging of the four English language skills. Majority of EFL students struggle with reading comprehension due to the lack of vocabulary, poor comprehension of text cohesiveness, and failure to recall prior knowledge (Tran \& Phuong, 2018). As a result, teachers' assistance and supervision are critical in facilitating their reading comprehension, and the ultimate goal of reading instruction is to enable students to become independent readers. One approach which can exploit students' reading ability is using visual aids generally and pictures particularly in teaching reading and specifically in pre-reading stage. According to Shabiralyani et al (2015), "visual aids are those sensory objects or images which initiate or stimulate and support learning". Alhaisoni (2017) claimed that pictures which are one of visual aids used in teaching language can be employed as pre-reading activities to recall prior knowledge of students. The author further emphasized that using pictures in pre-reading stage can help teachers raise their students' interests to reading English texts. 
DOI: $\underline{10.51386 / 25815946 / \mathrm{ijsms}-\mathrm{v} 4 \mathrm{i} 5 \mathrm{p} 123}$

Volume: 4 Issue: 5

September to October 2021

https://www.ijsmsjournal.org

Noticeably, according to Wright (1989), using pictures as pre-reading activities can help students focus, remember; and involve them in learning process. However, this potential technique still remains less researched in the context of high schools in Vietnam. The current research is aimed to investigate high school EFL teachers' perceptions towards the benefits that pictures used in pre-reading stage as well as some possible problems they may face when using pictures in teaching reading skill.

\subsection{Teacher's perception}

\section{LITERATURE REVIEW}

Different researchers have given the variety of definitions about teacher's perception. Perception is the act of observing something in the environment and forming thoughts, beliefs, attitudes, and judgments about it. According to Jordan (1989), "perception is the term that relates to the human ability to analyze, interpret, and attach meaning to the information acquired via the sensory system," i.e., seeing, hearing, smelling, tasting, and touching". The term "perception" is used as the closet meaning of a number of terms as "belief". According to Borg (2001), beliefs not only cause people to become more sensitive to the world, but they also have a significant impact on how new information is seen and accepted. In education, teachers' belief is relevant to "pedagogic belief" or "individual's teaching". Richards (1998) also claims that teachers' belief as "the information, attitudes, values, expectations, theories, and bring with them to the classroom". Furthermore, teachers' belief or teachers' perception is a central construct which deals with human behavior and influences teachers' consciousness, teaching attitude, teaching methods, teaching policies, teaching behavior and learners' development. Perception is defined as a method, a style of thinking, or a point of view in this study. Teachers' perceptions in language instruction are related to the ideas and theories that they use in teaching, language, learning, and their students. Teachers' perceptions are said to be formed by experience, observation, training, and other sources, and play a significant role in their teaching in classroom practices.

\subsection{Pictures in language teaching}

\subsubsection{Definition of pictures}

Pictures along with illustrations and flash cards are visual aids which are commonly used in teaching English. They are believed to help both teachers and students (Uematsu, 2012). According to Hill (1990), pictures are images that are brought into language classroom. They can be drawn, taken from books, newspapers and magazines to facilitate students' learning (Harmer, 2001). Felma (2007) further indicates that pictures are visual materials that can be used to motivate the students in producing positive attitudes towards English and to teach or reinforce language skills. In the present study, picture is viewed as a visual representation of something, such as a person or scene, produced on a surface, as a photograph, painting and etc.). Pictures are employed to attract students and engage them in reading activities in pre-reading stage.

\subsubsection{Pictures' roles in English language teaching}

Robert (1984) says "A picture is not only worth a thousand words; it can also be used in a wide variety of teaching activities". It can be said that many advantages of using pictures are sprout when they are used to students in pre-reading stage. There is extensive evidence in the literature to support the claim that the use of digital visual materials - either static image in the instruction process can raise students' attention and can also significantly improve their performance in retention and comprehension tasks (Hoban \& Ormer, 1970; Katsioloudis, 2007). Using pictures makes students learn the language easily especially in pre-reading because pictures make the teaching and learning process more actual. What is more, pictures can make students interested in joining activities and make the lesson's content more comprehensive. Brister (2010) states that using visual aids as pictures make learners more interested in the topic of the lesson and make the class more active and livelier. Likewise, Calder (1966, as cited in Girma, 1983) stated that psychologists have found that $84 \%$ of what we learn we get from seeing; $13 \%$ of what we learn we get from hearing; and only $3 \%$ we learn in other ways. This implies that most of what we learn we get through visual medium. They help students associate with the presented material in a meaningful way (Uberman, 1998). Moreover, for teachers, pictures can be reused in different classes. They are easily kept, and useful for various types of activities in pre-reading stage (brainstorming, previewing, predicting and discussing). Indeed, some researchers found that whenever EFL teachers teach the lesson with the support of pictures, learners get more stimulated because pictures help them to become more attentive. As a consequence, students take part in classroom activities (Adeyanju, 2001). 
DOI: $\underline{10.51386 / 25815946 / \mathrm{ijsms}-\mathrm{v} 4 \mathrm{i} 5 \mathrm{p} 123}$

Volume: 4 Issue: 5

September to October 2021

https://www.ijsmsjournal.org

Likewise, the researcher Dempsey (2009) has claimed that visual aids help hold the audience's attention. What is more, pictures can reinforce the message of the lesson. A number of studies demonstrating that the audience members will better understand message and recall of the key points longer when teachers use effective visual aids or pictures (Dempsey, 2009). In sum, pictures can be utilized to clarify a difficult, convoluted, or huge subject or to emphasize critical points (Stice, 1987). Pictures help learners more involved in their lessons and become more interested in what they are going to learn. In the context of teaching reading comprehension, pictures show their roles in stimulating students' prior knowledge and make them more curious of what they are reading.

\subsubsection{Possible difficulties of using pictures}

Although using pictures brings about a lot of advantages, there are still some drawbacks. First of all, Underhill (1987) pointed out with a visual stimulus, there is a danger that the learner will miss the point of a picture or story, for personal or cultural reason. In another reference, Arief S. Sadian (2007) states several disadvantages of pictures. They are believed only to emphasize on eye concentration. Some complicated pictures are less effective for the teaching and learning process. In some situations, students who limited linguistic competence are unable to express what they have seen in the pictures. Furthermore, choosing the right images can be a problem for some teachers. Some images may not describe the full message that the teacher intends to present. Besides that, pictures are only two-dimensional and therefore they do not give the depth of whatever it is trying to portray. In addition, making pictures is time-consuming and cost. Some teachers have to print the pictures out to apply in vocabulary lesson. It takes time to find the correct pictures for a specific type of activity for a beginning teacher who lacks own collection. Teachers had to spend spare time at home to plan, design, and prepare the suitable materials (Purwoningsih, 2007). Furthermore, if the pictures are small or unclear, they may not attract students to see what is being shown. Hence, teachers should choose big and clear pictures for everyone in classroom can see clearly. Last but not least, Dempsey (2009) has also indicated that if pictures are not used appropriately, learners may lose concentration on the pictures and disregard the teachers' message, especially if the visual aids are confusing.

\subsection{Teaching reading skill}

According to Charlotte \& Barbara (2004), each lesson has a reading goal, and each extension modifies the reading purpose, causing the reader's emphasis to shift. It means that the goal of reading can be achieved if readers are provided with the most effective ways of comprehending the material. Reading may be defined as a process that incorporates vision and response in order to understand and interpret reading content with the goal of obtaining information and expanding our knowledge. The goal of learning to read in a language has always been to get access to literature written in that language. Reading resources for language training have been selected from literary books that represent "higher" cultural forms. Teachers must be concerned about the materials utilized when teaching reading. It's also worth thinking about the topics and sorts of reading materials. These subjects and reading texts should be tailored to the individual students. Reading scientific texts may be a priority if the pupils are science students. Furthermore, for high school students, the aims of reading are to identify key textual content, to answer a specific question, and to determine which area of a text to begin learning (Naf"an \& Miftahul, 2012). Teachers must decide what the objective of reading will be in the reading class. It is reading for pleasure or reading for getting to understand the passage. If the purpose of reading that will be done is for getting understanding the passage, the topic of reading text should be prepared before.

\subsection{Pre-reading activities}

Pre-reading activities are activities that are used to elicit prior knowledge of the reading content from students. The activities are designed to give students the background knowledge they will need to have a better understanding of a text when they interact with it (Alemi \& Ebadi, 2010; Wilen \& Clegg, 1986). Pre-reading activities in the EFL classroom are useful because students can easily understand what they are reading and by activating their prior knowledge during the reading process. There are several roles of pre-reading activities in the literature. Paul \& Christopher (2017) confirm the important role of pre-reading activities in teaching reading. These activities help students build schemata and make connection between their own background knowledge with the information in the text. Moreover, pre-reading activities are used to apply questioning strategies that 
DOI: $\underline{10.51386 / 25815946 / \mathrm{ijsms}-\mathrm{v} 4 \mathrm{i} 5 \mathrm{p} 123}$

allow students to begin reading a given text (Amalia \& Devanti, 2016). Similarly, Abraham (2002) asserts that teachers need to give attention into pre- reading activities to activate the students' "schemata" by helping them recognize the knowledge that they already have about the topic of the text. Thuy et al. (2018) also shared same opinion about the goals of pre-reading activities are to activate the students' knowledge of the subject, to provide any language preparation that might be needed for coping with the passage, and eventually to motivate the learners reading the text. Thuraisingam et al. (2017) believed that activating prior knowledge awareness can facilitate comprehension of the reading process. In a word, stimulating students' prior knowledge of the given text not only help them understand the text easily but it can also increase the motivation and confidence of students in expressing their personal views and ideas about the text.

\subsection{Research questions}

\section{METHODOLOGY}

The main aim of this research is to investigate the perceptions of EFL teachers towards using pictures in pre-reading stage to high school students. Specifically, this study was to examine the merits and demerits of this teaching visual aid. Therefore, the study is guided by the following questions:

1. What are high school EFL teachers' perceptions of the benefits of using pictures in pre-reading stage?

2. What are possible difficulties EFL teachers may face when using pictures in pre-reading stage?

\subsection{Research Design}

The current study was designed as descriptive research with a mixed method employed to collect the data. As Bouma (1996) has stated, "both qualitative and quantitative approaches are essentials to the research process in social sciences". For quantitative data, a five-point Likert questionnaire was deployed to explore the high school EFL teachers' perceptions of using pictures in pre-reading stage as well as to find out possible challenges they may face when using pictures as pre-reading activities. Then, to collect qualitative data, a semistructure interview was employed to gain deeper ideas and thoughts from the participants through informal conversations.

\subsection{Participants}

The study recruited 30 EFL teachers who have been working in several high schools in the Mekong Delta, Vietnam. The samples consisted of ten males and twenty females. They all got bachelor degrees in English language education and eight of them have completed master program in English language education in Can Tho University. The typical feature of the group is that they are all enthusiastic and make great efforts in English language teaching and have experience in teaching all four skills of language to high school students.

\subsection{Research instruments}

\subsubsection{Questionnaire}

In order to collect the quantitative data, a questionnaire was utilized as the first research instrument. The questionnaire was designed based on the literature reviewed earlier with two main sections. Section one was aimed at collecting participants' demographic information and section two was the main part included 28 closed-ended questions. There were 15 items asking about the benefits of pictures in pre-reading stage and 13 items eliciting about possible difficulties that EFL teachers may face when using pictures in pre-reading stage. In particular, the items in section 2 of the present study were designed with Likert scale rating on five-point categories, namely (1) strongly disagree, (2) disagree, (3) neutral, (4) agree and (5) strongly agree.

The questionnaire was piloted on eight teachers who have experienced in teaching English at high schools more than five years. The data of piloting questionnaire was gathered and checked the reliability. Cronbach Alpha Test was run and the was medium $\boldsymbol{\alpha}=\mathbf{. 7 2 3}$. This result showed that the questionnaire was reliable enough to be used for collecting data of this survey.

\subsubsection{Semi-structured interviews}

The semi - structured interviews were conducted in order to gain deeper understanding of participants about the use of pictures in pre-reading stage. The interview content focuses on (1) the benefits of using pictures in pre-reading stage and (2) the possible difficulties of using pictures in pre-reading stage. 
DOI: $\underline{10.51386 / 25815946 / \mathrm{ijsms}-\mathrm{v} 4 \mathrm{i} 5 \mathrm{p} 123}$

Volume: 4 Issue: 5

September to October 2021

https://www.ijsmsjournal.org

The answers from the interview were recorded with the agreement of the interviewees for later analysis. All data were kept confidentially. As the language used in the semi-structured interview was Vietnamese to make the data was accurate and clear, transcription of the data was made later on. The interview was conducted online via Zalo social networking due to the spread of the Covid 19 pandemic.

\section{FINDINGS}

\subsection{Findings from the questionnaire}

In the questionnaire, there were 28 items designed to collect data. The participants answered the questionnaire according to a five - point scale of individual items which is ranged from strongly disagree to strongly agree. The data obtained from the questionnaire were subjected to the Statistics Package for the Social Science (SPSS) version 22.0 for the data analysis. The Cronbach Alpha test was run to check the reliability of the questionnaire. The results showed that reliability coefficient of the questionnaire was demonstrated high $(\boldsymbol{\alpha}=$ $.892)$.

\subsubsection{The benefits of using pictures in pre-reading stage}

In order to obtain full understanding of the EFL teachers' perceptions toward the benefits of pictures in teaching pre-reading for high school students, Descriptive Statistics Test is used and the results are displayed in the Table 1 below.

\section{TABLE 1: THE RESULTS OF DESCRIPTIVE STATISTICS TESTS ABOUT THE BENEFITS OF USING PICTURES IN PRE-READING STAGE}

\begin{tabular}{|c|c|c|c|}
\hline Items & $\mathbf{N}$ & Mean & S.D \\
\hline 1. Pictures allow students to recall the information easily. & 30 & 4.20 & .714 \\
\hline 2. Through pictures, students can understand the text better. & 30 & 4.43 & .679 \\
\hline 3. Pictures help students read a text quickly. & 30 & 3.63 & 1.066 \\
\hline 4. Pictures enable the students to be motivated to read the text & 30 & 4.40 & .724 \\
\hline 5. Pictures make students think more about the text. & 30 & 4.27 & .691 \\
\hline $\begin{array}{l}\text { 6. Pictures help students connect what they have already known with what } \\
\text { they are learning from the text. }\end{array}$ & 30 & 4.03 & .765 \\
\hline 7. Pictures can involve students in the text that they are going to read. & 30 & 4.13 & .730 \\
\hline 8. Pictures help students follow the text easily. & 30 & 3.97 & .809 \\
\hline 9. Pictures help students know the purpose of the reading text. & 30 & 4.17 & .834 \\
\hline $\begin{array}{l}\text { 10. Pictures help students predict the topic and contents of the text before } \\
\text { reading. }\end{array}$ & 30 & 4.10 & .803 \\
\hline 11. Pictures stimulate students' critical thinking. & 30 & 3.77 & .817 \\
\hline 12. Pictures make students 'classroom atmosphere more enjoyable. & 30 & 4.07 & .640 \\
\hline 13. Pictures make students more confident to deal with the text. & 30 & 4.13 & .900 \\
\hline 14. Pictures encourage students to learn from their friends' ideas & 30 & 4.00 & .695 \\
\hline 15. Pictures make students more involved in reading. & 30 & 4.33 & .758 \\
\hline Overall Mean & & 4.11 & .217 \\
\hline
\end{tabular}


DOI: $\underline{10.51386 / 25815946 / \mathrm{ijsms}-\mathrm{v} 4 \mathrm{i} 5 \mathrm{p} 123}$

Volume: 4 Issue: 5

September to October 2021

https://www.ijsmsjournal.org

As shown in Table 1, the overall mean score of the benefits of using pictures in pre-reading stage is in high range $(\mathrm{M}=4.11, \mathrm{SD}=.217)$. The result indicates that the high school EFL teachers have positive beliefs or perceptions of the benefits of pictures in pre-reading stage. When looking at the items in Table 1, it can be seen that most of the participants are aware of the usefulness of pictures in teaching reading skill. Most of them strongly agreed that pictures can help students read the text better $(M=4.43)$. Other items such as "Pictures enable the students to be motivated to read the text", "Pictures make students more involved in reading", "Pictures make students think more about the text" also received high support from the participants (M=4.40, $\mathrm{M}=4.33$, and $\mathrm{M}=4.27$ respectively).

To examine whether there is a significant difference between the participants' groups by their gender and by their qualification, an Independent Samples t- Test was run on the mean scores and the data are shown in Table 2 below.

TABLE 2: COMPARISON THE MEAN SCORES ON THE BENEFITS OF PICTURES USED IN PREREADING STAGE BY GENDER AND BY QUALIFICATION

\begin{tabular}{cccccc}
\hline & & Mean & Std. Deviation & T & Sig. \\
\hline \multirow{2}{*}{$\begin{array}{c}\text { Perceptions } \\
\text { towards the } \\
\text { benefits of pictures } \\
\text { used in pre-reading } \\
\text { stage }\end{array}$} & female & 4.17 & 0.26 & & \\
\cline { 2 - 5 } & male & 3.99 & 0.21 & 2.10 & 0.05 \\
\cline { 2 - 5 } & MA degree & 4.06 & 0.16 & 2.05 & 0.05 \\
\hline
\end{tabular}

The results from Table 2 reveal that there is significant difference in the mean scores between female teachers $(\mathrm{M}=4.17, \mathrm{SD}=0.26)$ and male teachers $(\mathrm{M}=3.99, \mathrm{SD}=0.21) ;(\mathrm{t}=2.10$, sig. $=0.05)$. The data also show that the mean scores of the perceptions towards the use of pictures in pre-reading stage of the teachers holding BA degree and MA degree $(\mathrm{t}=2.05$, sig. $=0.05)$ are significantly different.

Then, One-way ANOVA Test was conducted to check if there is difference among the participants by their teaching experience and the results are displayed in Table 3 below.

TABLE 3. DESCRIPTIVE STATISTICS OF PERCEPTIONS TOWARDS USING PICTURES IN PREREADING STAGE ACCORDING TO PARTICIPANTS' TEACHING EXPERIENCE

\begin{tabular}{|c|c|c|c|c|c|c|c|c|}
\hline & \multirow[b]{2}{*}{$\mathbf{N}$} & \multirow[b]{2}{*}{ Mean } & \multirow[b]{2}{*}{$\begin{array}{c}\text { Std. } \\
\text { Deviation }\end{array}$} & \multirow[b]{2}{*}{$\begin{array}{l}\text { Std. } \\
\text { Error }\end{array}$} & \multicolumn{2}{|c|}{$\begin{array}{l}\text { 95\% Confidence } \\
\text { Interval for Mean }\end{array}$} & \multirow[b]{2}{*}{ Minimum } & \multirow[b]{2}{*}{ Maximum } \\
\hline & & & & & $\begin{array}{l}\text { Lower } \\
\text { Bound }\end{array}$ & $\begin{array}{l}\text { Upper } \\
\text { Bound }\end{array}$ & & \\
\hline Under 3 years & 7 & 3.87 & .576 & .218 & 3.33 & 4.40 & 3.20 & 4.80 \\
\hline $\begin{array}{l}\text { From } 3 \text { to } \\
\text { under } 7 \text { years }\end{array}$ & 10 & 4.32 & .226 & .072 & 4.16 & 4.48 & 4.07 & 4.67 \\
\hline Over 7 years & 13 & 4.08 & .473 & .131 & 3.79 & 4.36 & 3.47 & 4.87 \\
\hline Total & 30 & 4.11 & .455 & .083 & 3.94 & 4.28 & 3.20 & 4.87 \\
\hline
\end{tabular}


DOI: $\underline{10.51386 / 25815946 / \mathrm{ijsms}-\mathrm{v} 4 \mathrm{i} 5 \mathrm{p} 123}$

Volume: 4 Issue: 5

September to October 2021

https://www.ijsmsjournal.org

The results from Table 3 show the mean scores of attitudes among EFL teachers who gained from 3 years to under 7 years of teaching $(\mathrm{M}=4.32, \mathrm{SD}=.226)$ was higher than that of the two other groups of teachers: those experiencing under 3 years $(M=3.87, \mathrm{SD}=.576)$ and those teaching over 7 years $(\mathrm{M}=4.08, \mathrm{SD}$ $=.473)$. It is clear that EFL teachers with experience of 3 years to under 7 years held the highest beliefs towards the use of pictures in pre-reading stage contrasted with the EFL teachers gaining under 3 years of teaching experience who indicated the lowest.

TABLE 4. DIFFERENCES BETWEEN TEACHING EXPERIENCE GROUPS

\begin{tabular}{lccccc}
\hline & Sum of Squares & df & Mean Square & F & Sig. \\
\hline Between Groups & .876 & 2 & .438 & 2.299 & .120 \\
\hline Within Groups & 5.143 & 27 & .190 & & \\
\hline Total & 6.019 & 29 & & & \\
\hline
\end{tabular}

One-way ANOVA analysis was employed to look into the differences in the perceptions of the respondents towards the use of pictures in pre-reading stage regarding their teaching experience. The results from Table 4 indicate that when being compared between groups and within groups, there is no difference in perceptions of the EFL teachers regarding their teaching experience $(F=9.732$, sig. $=0.120>0.05)$. Then, the analysis of Multiple Comparison was also conducted to determine which groups are statistically different and results displayed in Table 5 below.

TABLE 5. MULTIPLE COMPARISONS

\begin{tabular}{llccccc}
\hline & & & & & \multicolumn{2}{c}{ 95\% Confidence } \\
Interval
\end{tabular}

*. The mean difference is significant at the 0.05 level.

Table 5 shows that the statistical difference is significant between EFL teachers teaching under 3 years and those teaching from 3 to under 7 years (sig. $=0.044<0.05$ ). However, there is no statistical difference between EFL teachers of over 7 years and the other two groups (sig. >0.05). It can be concluded that EFL 
DOI: $\underline{10.51386 / 25815946 / \mathrm{ijsms}-\mathrm{v} 4 \mathrm{i} 5 \mathrm{p} 123}$

Volume: 4 Issue: 5

September to October 2021

https://www.ijsmsjournal.org

teachers with 3 years to under 7 years held different beliefs towards the usefulness of pictures contrasted with the other two groups regarding teaching experience.

4.1.2. Possible difficulties that prevent high school EFL teachers from using pictures in pre-reading stage

To explore EFL teachers' perceptions of difficulties in using pictures to teach pre-reading for high school students, thirteen items of the questionnaire were conducted (item 16 to 28). The Descriptive Statistics data are shown in Table 6 below.

TABLE 6. DESCRIPTIVE STATISTICS OF PERCEPTIONS OF POSSIBLE DIFFICULTIES IN USING PICTURES IN PRE-READING STAGE

\begin{tabular}{|c|c|c|c|}
\hline Items & $\mathbf{N}$ & Mean & S.D \\
\hline 16. I need a lot of time to prepare pictures. & 30 & 3.77 & .935 \\
\hline $\begin{array}{l}\text { 17. I found that some pictures could only emphasize my } \\
\text { students' eye concentration. }\end{array}$ & 30 & 4.23 & .774 \\
\hline $\begin{array}{l}\text { 18. Students with limited linguistic competence prevent them } \\
\text { from expressing what they have seen in the pictures. }\end{array}$ & 30 & 4.20 & .714 \\
\hline 19. Preparing pictures usually costs me much. & 30 & 4.33 & .606 \\
\hline 20. Time allotted for teaching reading is not enough. & 30 & 4.17 & .834 \\
\hline $\begin{array}{l}\text { 21. The topics of some reading texts are difficult to choose } \\
\text { pictures. }\end{array}$ & 30 & 4.00 & .910 \\
\hline $\begin{array}{l}\text { 22. When pictures are not used appropriately, my students may } \\
\text { lose concentration on the pictures. }\end{array}$ & 30 & 4.00 & .830 \\
\hline 23. Some pictures are not big enough for the large-size class. & 30 & 4.00 & .587 \\
\hline $\begin{array}{l}\text { 24. Large pictures can be hard to lug from classroom to } \\
\text { classroom. }\end{array}$ & 30 & 4.23 & .679 \\
\hline 25. If I overuse pictures, students may feel bored with them. & 30 & 3.77 & 1.104 \\
\hline 26. Not all kinds of pictures are available to find. & 30 & 3.37 & .999 \\
\hline $\begin{array}{l}\text { 27. Unless properly cared for, pictures can be easily torn, } \\
\text { disordered or lost }\end{array}$ & 30 & 3.97 & .718 \\
\hline $\begin{array}{l}\text { 28. Some pictures may not describe the full message which I } \\
\text { intend to present }\end{array}$ & 30 & 3.47 & .900 \\
\hline \multicolumn{2}{|l|}{ Overall mean } & 3.96 & 0.296 \\
\hline
\end{tabular}

In general, the mean score of the perceptions towards the difficulties that EFL teachers in high schools may face when using pictures in pre-reading stage is rather high $(\mathrm{M}=3.96)$. As can be seen in Table 6 , most of the respondents highly agreed that preparing pictures usually costs them much $(M=4.33)$. It means that making pictures costs so much money that the EFL teachers could not afford to use them in teaching reading. Majority of them admitted that they found that some pictures could only emphasize their students' eye concentration $(\mathrm{M}=4.23)$. Most of them reported that students with limited linguistic competence could not express what they 
DOI: $\underline{10.51386 / 25815946 / \mathrm{ijsms}-\mathrm{v} 4 \mathrm{i} 5 \mathrm{p} 123}$

Volume: 4 Issue: 5

September to October 2021

https://www.ijsmsjournal.org

have seen in the pictures $(M=4.20)$. Other problems such as "time allotted for teaching reading is not enough" $(\mathrm{M}=4.17)$, "the topics of some reading texts are difficult to choose pictures" $(\mathrm{M}=4.00)$, "when pictures are not used appropriately, my students may lose concentration on the pictures" $(M=4.00)$ and "Some pictures are not big enough for the large-size class" $(\mathrm{M}=4.00)$ received high mean scores. It can be inferred that many problems hinder the EFL teachers in high schools from using pictures to lead in their reading lessons.

To examine whether the possible difficulties differed among the EFL teachers regarding their genders and their qualifications, the Independent -Samples $\mathrm{T}$ Test was run on the mean scores and the data are presented in Table 7 below.

\section{TABLE 7. DESCRIPTIVE STATISTICS OF PERCEPTIONS TOWARDS THE DIFFICULTIES OF USING PICTURES REGARDING GENDER AND QUALIFICATIONS}

\begin{tabular}{cccccc}
\hline & & Mean & Std. Deviation & T & Sig. \\
\hline \multirow{2}{*}{$\begin{array}{c}\text { Perceptions of } \\
\text { difficulties when } \\
\text { using pictures in } \\
\text { pre-reading stage }\end{array}$} & male & 3.89 & 0.266 & & \\
\cline { 2 - 4 } & female & 4.00 & 0.862 & 0.199 \\
\cline { 2 - 4 } & BA degree & 3.94 & 0.278 & & \\
\cline { 2 - 5 } & MA degree & 4.03 & 0.408 & & 0.680 \\
\hline
\end{tabular}

The data from Table 7 reveal that the mean score of male teachers $(M=4.00)$ is higher than that of female teachers $(M=3.89)$. However, when being compared, the results indicate that there is no significant difference in the mean scores for male teachers and female teachers $(t=-0.862 ;$ sig. $=0.199>0.05)$. Similarly, the mean score of teachers with BA degree $(M=3.94)$ is found lower than that of the teachers with MA degree $(\mathrm{M}=4.03)$. Nevertheless, no significant difference was found in the possible difficulties between teachers with BA degree and teachers with MA degree $(\mathrm{t}=-0.680$; sig.= 0.252). It means that both groups with different qualifications shared the same perceptions of the possible difficulties.

Next, One-way ANOVA Test was run to check if there are any differences among the participants by their teaching experience and the results are displayed in Table 8 below.

TABLE 8. DESCRIPTIVE STATISTICS OF PERCEPTIONS TOWARDS DIFFICULTIES EFL TEACHERS MAY FACE WHEN USING PICTURES IN PRE-READING STAGE REGARDING THEIR TEACHING EXPERIENCE

\begin{tabular}{|c|c|c|c|c|c|c|c|c|}
\hline & \multirow[b]{2}{*}{$\mathbf{N}$} & \multirow[b]{2}{*}{ Mean } & \multirow[b]{2}{*}{$\begin{array}{c}\text { Std. } \\
\text { Deviation }\end{array}$} & \multirow[b]{2}{*}{ Std. Error } & \multicolumn{2}{|c|}{$\begin{array}{l}\text { 95\% Confidence } \\
\text { Interval for Mean }\end{array}$} & \multirow[b]{2}{*}{ Minimum } & \multirow[b]{2}{*}{ Maximum } \\
\hline & & & & & $\begin{array}{l}\text { Lower } \\
\text { Bound }\end{array}$ & $\begin{array}{l}\text { Upper } \\
\text { Bound }\end{array}$ & & \\
\hline$<3$ years & 7 & 3.92 & .458 & .17320 & 3.4990 & 4.3467 & 3.31 & 4.54 \\
\hline $3-<7$ years & 10 & 4.14 & .331 & .10459 & 3.9024 & 4.3756 & 3.54 & 4.62 \\
\hline$>7$ years & 13 & 3.84 & .393 & .10904 & 3.6078 & 4.0830 & 3.00 & 4.38 \\
\hline Total & 30 & 3.96 & .398 & .07272 & 3.8126 & 4.1101 & 3.00 & 4.62 \\
\hline
\end{tabular}


DOI: $\underline{10.51386 / 25815946 / \mathrm{ijsms}-\mathrm{v} 4 \mathrm{i} 5 \mathrm{p} 123}$

Volume: 4 Issue: 5

September to October 2021

https://www.ijsmsjournal.org

The results from Table 8 show that the mean scores of difficulties among EFL teachers who experienced from 3 years to under 7 years of teaching $(\mathrm{M}=4.14, \mathrm{SD}=.331)$ was greater than that of the two other groups of teachers: those experiencing less than 3 years $(\mathrm{M}=3.92, \mathrm{SD}=.458)$ and those teaching over 7 years $(\mathrm{M}=3.84, \mathrm{SD}=.393)$. It should be checked whether there are any significant differences on the beliefs towards the difficulties of using pictures in pre-reading stage regarding their teaching experience.

TABLE 9. DIFFERENCES BETWEEN TEACHING EXPERIENCE GROUPS

\begin{tabular}{lccccc}
\hline & Sum of Squares & df & Mean Square & F & Sig. \\
\hline Between Groups & .501 & 2 & .250 & 1.649 & .211 \\
\hline Within Groups & 4.099 & 27 & .152 & & \\
\hline Total & 4.600 & 29 & & & \\
\hline
\end{tabular}

However, the analysis of One-way ANOVA test reveals that there is no significant difference in the perceptions of the respondents towards the difficulties of using pictures in pre-reading stage regarding their teaching experience $(F=1.649$, sig. $=0.211>0.05)$. Then, the analysis of Multiple Comparison was also conducted to determine which groups are statistically different from the others and the results are shown in Table 10 below.

TABLE 10. MULTIPLE COMPARISONS

\begin{tabular}{|c|c|c|c|c|c|c|}
\hline \multirow[b]{2}{*}{$\begin{array}{l}\text { (I) English Language } \\
\text { Teaching Experience }\end{array}$} & \multirow[b]{2}{*}{$\begin{array}{l}\text { (J) English Language } \\
\text { Teaching Experience }\end{array}$} & \multirow{2}{*}{$\begin{array}{c}\text { Mean } \\
\text { Difference } \\
\text { (I-J) }\end{array}$} & \multirow[b]{2}{*}{ Std. Error } & \multirow[b]{2}{*}{ Sig. } & \multicolumn{2}{|c|}{$\begin{array}{l}\text { 95\% Confidence } \\
\text { Interval }\end{array}$} \\
\hline & & & & & $\begin{array}{l}\text { Lower } \\
\text { Bound }\end{array}$ & $\begin{array}{l}\text { Upper } \\
\text { Bound }\end{array}$ \\
\hline \multirow[t]{2}{*}{$<3$ years } & $3-<7$ years & -.21614 & .19202 & .270 & -.6101 & .1779 \\
\hline & Over 7 years & .07747 & .18267 & .675 & -.2973 & .4523 \\
\hline \multirow[t]{2}{*}{$3-<7$ years } & $<3$ years & .21614 & .19202 & .270 & -.1779 & .6101 \\
\hline & Over 7 years & .29362 & .16390 & .084 & -.0427 & 6299 \\
\hline \multirow[t]{2}{*}{ Over 7 years } & $<3$ years & -.07747 & .18267 & .675 & -.4523 & .2973 \\
\hline & $3-<7$ years & -.29362 & .16390 & .084 & -.6299 & .0427 \\
\hline
\end{tabular}

*. The mean difference is significant at the 0.05 level.

Table 10 indicates that there is no statistical difference between the groups of EFL teachers with various teaching experience. It can be concluded that all of the EFL teachers shared the same views on the problems they may face when using pictures in pre-reading stage. 
DOI: $\underline{10.51386 / 25815946 / \mathrm{ijsms}-\mathrm{v} 4 \mathrm{i} 5 \mathrm{p} 123}$

Volume: 4 Issue: 5

September to October 2021

https://www.ijsmsjournal.org

\subsection{Interview results}

The semi-structured interviews were conducted to gain insight into teachers' perception toward the benefits as well as the possible difficulties of using pictures in pre-reading stage for high school students. In particular, the questions were raised to probe the participants' viewpoints about using pictures, relating to the strengths and weaknesses of utilization pictures in pre-reading stage. The two sides of using pictures are presented in the following sections.

\subsubsection{The benefits of using pictures in pre-reading stage}

The interview data show that majority of the EFL teachers had high perceptions of using images to teach in pre-reading stage to high school students. Most of them believe that it is effective to use pictures to warm up the lesson and to provoke students on what they are going to read. It can be said that the respondents think pictures are applicable in language classroom. These ideas are illustrated by Teacher B and Teacher F as below:

"I usually use pictures to elicit about the text and help them guess what they are going to read. In addition, my students are curious about their reading text. To be honest, pictures are very effective aids which can be used in pre-reading stage." (Teacher B)

"I prefer using pictures or images to help my students connect what they have already known with what they are going to read. I think their imaginary is more enhanced. Some new words can be presented through the pictures, too." (Teacher F)

Teacher B, C and E shared the view that they may use pictures from different sources to assist their students to interact with the text that they are going to read. They all think that employing images in the prestage can help students predict some information in the text and activate their schemata. The results from the interview are consistent with what has been found in the questionnaire.

Teacher A and $\mathrm{F}$ further confirmed that

"Pictures can be good tools to trigger students to associate prior knowledge with the text. Teachers can exploit different kinds of graphics to lead students in the reading lesson." (Teacher A)

"Like other pre-reading activities, pictures appear to make the class become more dynamic, their prior knowledge which is connected with the text is activated". (Teacher F)

Additionally, the interviewees reported that pictures can create classroom atmosphere more enjoyable. In their experience, they said that showing pictures, especially the ones that they collected from the Internet make their students involved in the lesson more. They are eager to show their guess and some of them do not feel shy. The classroom's atmosphere becomes more enjoyable. This can be exemplified by teacher C:

"Whenever I prepare pictures to show in the pre-stage of a reading lesson, my students are willing to answer my questions and some of them are more energetic. Through pictures, I can ask some questions to involve them in the lesson easily." (Teacher C)

In reality, some of them admitted that pictures are not only used as pre-reading activity but they are also exploited in pre-stage of other skills such as writing and speaking.

"My students are more interested in the topic that they are going to learn and sometimes question me about the pictures. In fact, pictures are very effective to motive my students in all four skills of English."

In responding to the questions conducted in the interviews, some of them asserted through pictures their students can interact with their friends more and become interested in what they are learning. 
DOI: $\underline{10.51386 / 25815946 / \mathrm{ijsms}-\mathrm{v} 4 \mathrm{i} 5 \mathrm{p} 123}$

Volume: 4 Issue: 5

September to October 2021

https://www.ijsmsjournal.org

Teacher E added that

"Thanks to pictures, some students follow the passage faster and know the purpose of the reading. In addition, images encourage them to give more thoughts as well as contribute more ideas to the lesson." (Teacher E)

It can be concluded that majority of the interviewed teachers held positive perceptions towards the usefulness of pictures implemented in pre-reading stage. The data from the interview supports the conclusion that EFL teachers have positive perceptions towards the pictures' benefits, and hence, it could be seen that pictures play an important role in teaching pre-reading. In comparison with the statistical data analysis, the findings from the interview are consistent.

\subsubsection{Possible difficulties that prevent English teachers from using pictures in pre-reading stage}

Even though pictures used in pre-reading stage bring some merits to both teachers and students, there are also some challenges they may face when using them. First of all, most of them reported that choosing the right image can be a problem for some teachers because the topics of some reading texts are difficult to choose pictures and some images may not describe the full message the teacher intends to present.

As teacher F reported,

"Although I know my students prefer seeing pictures, I have to quit the idea as it's too expensive to print in color for easy viewing by students. Moreover, the topics of some reading texts are difficult to choose appropriate pictures."

The interviewed teachers admitted that sometimes students limited linguistic competence prevents them from exploiting the pictures. In addition, two of them think that pictures only emphasize on students' eye concentration and are not helpful for other purposes.

For example, teacher D conceded that "sometimes I fail in using pictures to elicit ideas from students, they only have a look at them and keep silence."

All of the teacher participants concluded that pictures' size can cause problems as if they are too small or unclear, their students could not see well and they become useless. Hence, teachers should choose big and clear pictures for the whole class can see properly. The answers of respondent $\mathrm{C}$ and $\mathrm{F}$ are good examples of the findings:

"Choosing big and clear enough pictures is really challenging to me. Once I could not find the large size, my students did not see well and they became passive." (Teacher C)

"The good pictures are the ones that can show to the whole class and this is very difficult for me to choose one like that." (Teacher F)

Other teachers claimed that overusing pictures may ruin the teaching objectives and they may make the students feel bored. This idea is exemplified by Teacher B:

"Sometimes using pictures too much will also lead to boring children because they are already grown up, so it should be used in moderation so that students can remember what they teach and enjoy to learn pre-reading effectively. Furthermore, not all kinds pictures are available, I have to choose according to the criteria of the text" (Teacher B)

Teacher $\mathrm{C}$ added that

"When teachers choose a picture that is too complicated, students may misunderstand what the teacher wants to convey. Moreover, for large classes where children use small pictures, they can't see them from far away, but if they use too large pictures, it's cumbersome and difficult to carry from class to class." 
DOI: $\underline{10.51386 / 25815946 / \text { ijsms-v4i5p123 }}$

Volume: 4 Issue: 5

September to October 2021

https://www.ijsmsjournal.org

The interviewed participants maintained that although the teacher highly appreciated the benefits of pictures used in pre-reading stage, they may be reluctant to apply this kind of visual aids due to time constraints.

Some participants like teacher A and C responded that "The amount of time allotted for reading section in each unit in the textbook is often about 45 minutes. The pre-reading stage usually takes from three to five minutes. If the teacher wants to use pictures or other ways to activate students' background knowledge in some unfamiliar topics, this period of time is too limited. Therefore, some of us frequently ignore the activity to activate the schemata. We just pre-teach some new vocabulary related to the reading text, and then, let the students to read the text immediately to complete the reading tasks." (Teacher A, C)

It may be inferred that almost the interviewed teachers share the same views on the challenges of employing pictures in the pre-reading stage. The interview data support what has been explored from the quantitative source on EFL teachers' perceptions of the potential challenges of utilizing pictures. In other words, the data from the interview are consistent with the quantitative.

\section{DISCUSSION AND CONCLUSION}

The current study was carried out to explore the merits as well as shortcomings that high school EFL teachers may face when using pictures in pre-reading stage. The study was guided by two research questions with two instruments to gain the data.

\subsection{The benefits of using pictures in pre-reading stage}

The results from the quantitative data indicated that the participating teachers highly agreed on the benefits of using pictures in pre-reading stage $(M=4.11)$. Specifically, based on the results of the Descriptive Statistics, it can be concluded that using pictures in pre-reading stage are beneficial in activating students' schemata or their prior knowledge, providing language preparation and motivating the learners to read the text. In addition, the results from the semi-structured interviews ensured the data found from the questionnaire and it was apparent that the participating teachers recognized the significant benefits of pictures as pre-reading activity.

The findings of the current study are supported by the results of several previous studies and presented in three main categories as follow.

\section{Pictures can be used as pre-reading activity to activate students' schemata}

Activating students' prior knowledge before reading a text is one of the techniques that EFL teachers employ in teaching reading. The current study found that pictures can be an effective method of stimulating what students already know and connect it with the new thing which is the reading text. This result is consistent with Dolati's (2012) findings which confirmed that visual aids, including pictures can enhance the English language classroom. The finding also supported the previous research of Anaktototy1 and Huwae (2020), who scrutinized pictures one of the ways used in pre-reading stage or as pre-reading activities. Pictures can be used to brainstorm students' ideas on the reading topics, to develop their prediction skills and to increase their reading comprehension. Similarly, Izza (2016) claims that pictures are applicable tools that could enhance students' learning. Moreover, pictures bring real life into classroom through which students are provided context before reading a text and are helped to interpret the meaning of the text's new words.

\section{Pictures can be used to motivate students at early stage}

In the context of teaching English as a foreign language like in Vietnam, students' motivation is always paid much attention by EFL teachers. Thus, the present study has found that pictures can be used as effective tools to motivate EFL learners. The EFL teachers highly agreed that pictures enable students to be motivated to read the text. They reported that the classroom atmosphere more enjoyable and more active. These findings are supported by the study of Umatsu (2012) who believed that pictures can make reading become more holistic activity. He concluded that the beauty of pictures can attract students as well as have the power to engage them in reading a text. The results were also in line with what was found in Danan (1992)'s research. The author pointed out that the use of different visual aids, including pictures help improve students' motivation as well as 
DOI: $\underline{10.51386 / 25815946 / \mathrm{ijsms}-\mathrm{v} 4 \mathrm{i} 5 \mathrm{p} 123}$

Volume: 4 Issue: 5

September to October 2021

https://www.ijsmsjournal.org

their interaction in class. Furthermore, the findings of the present study also provide strong support for the results of the previous research of Do (2010) who confirmed that using pictures makes lessons more enjoyable and memorable. Likewise, Suciati (2009) added that using pictures make students more active and get involved in the new lesson easily as well as make them more understandable and do not feel bored with the teacher's explanation. The present study's findings were also similar to what was explored in the study of Miller (2011). $\mathrm{He}$ concluded that the language classroom environment that was created with the addition of the visual approaches facilitated the overall engagement of students in the lessons. The visual practices increase the level of social interaction in the classroom and stimulate communication needs among students. Similarly, Domin's (2007) study had the same finding with this study, it is claimed that visual stimuli are effective means of transferring information which help motivate and activate students, keep their attention, create a relaxed atmosphere and provide a context in which the students use new language.

\section{Pictures can be used to provide language preparation}

The EFL teachers of the current study had great concerns about using pictures in teaching pre-reading. Most of them agreed that using pictures can provide students language preparation. Palacios et al (2021) emphasized the use of images is a useful pedagogical tool to teaching reading that promotes student's participation, as they facilitate access to topics and the development of the target language. Moreover, it encourages reflection on learning and prevents the student to forget the information in the text. Moreover, Pan (2009) also emphasized that pictures can be a useful tool for reducing the cognitive load and thus supporting reading comprehension when they reflect the linguistic complexities of the text and contain a sufficient amount of information relative to the content. Because of this, EFL college teachers, textbook designers, and materials developers should choose pictures with caution; that is, pictures should match the text to assist students in comprehending what they have read in regard to both language and content they can reduce their talking time of leading in to the new topic through different types of visual aids. Furthermore, well-chosen visuals evoke an immediate response from learners in any class. This is very necessary because a personal reaction is the vital seed of meaningful language learning and visual aids also help to convey the meaning of new items of vocabulary, particularly concrete ones so that the teacher does not have to translate every single word into mother. In addition, visuals are of great help in bringing variety and interest into the classroom and focusing students ' attention on the subject. By visual aids, teachers motivate learners and stimulate their learning.

\subsection{EFL teachers' perceptions of possible difficulties of employing pictures to teach pre-reading to high school students}

The results of the questionnaires insisting possible difficulties that EFL teachers confront when using pictures in pre-reading stage. The overall mean score is 3.96 which is at the "agree" level of the five -point scale. It means that the teacher participants' perceptions towards possible difficulties is rather high. The participants shared some difficulties that they frequently faced while using pictures in pre-stage of reading, mostly focused on teachers' side and students' side. The results from both questionnaires and interviews reinforced the findings of the study.

The findings are somehow in line with research of Domin (2007), suggesting that EFL teachers who integrate visual aids as well as pictures in teaching can spend much time and much money. Teachers have to work on a tight budget that is a very important factor influencing the choice of teaching aids. The findings are confirmed in the study of Dolati (2012) pointing out that using visual aids takes teachers' time to prepare and as a result they ignore to use this in pre-stage. Domin (2007) has also informed that visual materials in presenting of the reality become more complicated when a teacher wants to introduce abstract concepts, feelings, process or actions. He or she has to search for other aids, the alternative methods should be rather gestures, mimes and body language than visual aids.

From the result of Oyarzo, Vargas and Reyes' (2008) research, realia and pictures are the techniques that are often left aside by teachers when presenting in pre-reading activities because the collection and creation of these resources are regarded as drawbacks, due to the lack of time, financial support and large classes. Another difficult in using pictures to teach in pre-reading stage is that the topics of some reading texts are 
DOI: $\underline{10.51386 / 25815946 / \mathrm{ijsms}-\mathrm{v} 4 \mathrm{i} 5 \mathrm{p} 123}$

Volume: 4 Issue: 5

September to October 2021

https://www.ijsmsjournal.org

difficult to choose pictures. Therefore, most EFL teachers self-proclaimed that choosing the right image can be problematic for some teachers because some images may not describe the full message the teacher intends to present. Furthermore, the findings also contribute to the prior research findings by Dwistanti \& Gita (2009) that suggested that pictures sometimes only emphasize on students' eye perception and they are not proactive to the questions that teachers eliciting from the pictures.

The current study also revealed that the participants showed their agreement on some difficulties which arose from the pictures themselves. Unless properly cared for, pictures can be easily torn, disordered or lost $(\mathrm{M}=3.97)$ and pictures can be hard to lug from classroom to classroom $(\mathrm{M}=4.23)$. Last but not least, there may be a misunderstanding of the size or angle of the pictures so some pictures may not describe the full message which teacher intend to present $(\mathrm{M}=3.47)$ and size of pictures is very limited for the students of the large class $(\mathrm{M}=$ 4.00).

\section{IMPLICATION AND CONCLUSION}

The present study aimed to investigate what high school EFL teachers' perceptions towards using pictures in pre-reading stage are. It also focused on the possible difficulties that the EFL teachers may encounter in using pictures in teaching preliminary activity.

Data were collected from two research instruments, namely the questionnaire and semi-structure interview. The participants in the study counted $30 \mathrm{EFL}$ teachers teaching at some high schools located in the Mekong Delta, Vietnam. Based on the results of the present study, it can be concluded that Vietnamese high school EFL teachers had positive perceptions towards the use of pictures in pre-reading stage. Most participants accepted that pictures play a role in stimulating the students' background information, motivating and providing language preparation. Based on this finding, it can be said that pictures are considered as one of several visual aids that may make students become more interested in the texts. When dealing with some unfamiliar reading topics, students lack interests of a topic, the reading article may seem difficult to understand and to comprehend. Thus, it is quite essential to activate students' desires to read through pictures which would make them decoding a message of the text more accurately and lead to a better comprehension. The findings also revealed that there was significant difference in EFL teachers' perceptions of the pictures' advantages regarding their gender and their qualifications but no difference was revealed by the participants' teaching experience.

Moreover, the results of the current study presented some possible difficulties that the high school EFL teachers may encounter while using pictures in pre-reading stage. These possible difficulties were the students' limited linguistic knowledge, unfamiliar reading text's topics, limited time for teaching reading, high cost and time-consuming in preparation, and the size of pictures. In reality, when preparing reading instruction, most of teachers focus on the while stage of the reading lesson. Thus, less planning and instructional time is dedicated to pre-reading activities as using pictures. This ignorance can have significant implications. Through pictures, students may easily get interests in what they are going to read. Furthermore, if pictures are exploited, students' schemata can be activated and easily to connect with the information presented in the reading articles. Therefore, to tackle these issues, some solutions should be considered. EFL teachers would like to acknowledge the pedagogical suggestions on using pictures in pre-reading stage. It is a recommendation that EFL teachers should spend some time getting themselves to pictures and studying how to use them skillfully. In term of time - consuming and cost, the teachers should share or exchange pictures with their colleagues. In fact, it will bring assorted pictures when the teachers share their materials together, it also helps them have appreciated choices in the use of pictures in teaching pre-reading for high school students. Additionally, choosing the right pictures was also mentioned as one of the major difficulties which the teacher had to face. The teachers should exploit some pictures which are available in the textbooks or choose the ones which are familiar with students. Even though pictures are playing a significant role in teaching process, it does not mean that the teachers should be dependent on pictures totally. They can incorporate or vary the strategies employed in pre-stage to make students not lose their interests. Noticeably, for the students, some of them still feel confused, distracted and difficult to understand the lesson when their teachers employ pictures to teach pre-reading stage. This problem is probably owing to the low effectiveness of the teachers' using visual aids, their unvaried types of visual aids 


\section{DOI: $\underline{10.51386 / 25815946 / \mathrm{ijsms}-\mathrm{v} 4 \mathrm{i} 5 \mathrm{p} 123}$}

Volume: 4 Issue: 5

September to October 2021

https://www.ijsmsjournal.org

applied. In order to solve these problems, the teachers should keep improving their pictures to become more attractive, creative and varied in types.

In conclusion, high school EFL teachers should always keep in mind two key words: creativity and imagination in order to exploit all kinds of visual aids that may be used in their lessons.

\section{ABOUT THE AUTHORS}

Nguyen Thi Yen Phuong is a teacher of English at a high school in Can Tho, Vietnam. She completed her bachelor degree of English in Education in 2015. She is currently an MA student at Can Tho University. Her research interests include reading strategies and teaching methodology.

Nguyen Huynh Trang is a lecturer of English Department, School of Foreign Languages, University of Economics Ho Chi Minh City. She completed her PhD degree in Linguistics at the English and Foreign Languages Hyderabad, India. Her research is about loanwords, second language acquisition, language skills and educational issues.

\section{REFERENCES}

[1] Abraham, P. (2002). Skilled Reading: Top-Down, Bottom-Up. Filed Notes, 10(2), 1-28.

[2] Adeyanju, L. (2001). Teachers' Perception of the Effects and Use of Learning Aids in Teaching: A case study of Winneba basic and secondary schools. Nigeria. University of Obafemi Awolowo.

[3] Alhaisoni, E. (2017). Prior Knowledge in EFL Reading Comprehension: Native and Nonnative EFL Teachers' Perceptions, Classroom Strategies and Difficulties Encountered. International Journal on Studies in English Language and Literature, 5(1), 3041 .

[4] Amalia, A.R., \& Devanti, Y.M (2016). The Use of Questioning Strategy to Improve Students' Reading Comprehension. Journal of English Language, Literature and Teaching

[5] Anaktototy1, K., Huwae, M. (2020). Assessing Teacher's Perception in the Use of Pre-Reading Activities in EFL Classroom. Universitas Pattimura Ambon, Indonesia

[6] Arief, S.S (2007), Media Pendidikan: pengertian, pengembangan, dan pemanfaatanya (Jakarta: PT. Raja Grafindo Persada, 2007), p. 31

[7] Azizifar, A., Roshani, S., Gowhary, H., \& Jamalinesari, A. (2015). The effect of prereading activities on the reading comprehension performance of ilami high school students. Procedia-Social and Behavioral Sciences, 192, 188-194.

[8] Bouma, G. (1996). Human ethics review and social sciences: Several emerging issues. Monash Bioethics Review, 15 (1), $10-11$.

[9] Borg, S. (2001) The distinctive characteristics of foreign language teachers. Language Teaching Research,10 (1), 3-31

[10] Brister, J. (2010) The Effect of Visual Aids on Learning. eHow UK: Science \& Education Retrieved 2016, March 22nd from http://www.ehow.co.uk/about_6395799_effect-visual-aids-learning.html

[11] Chia, H. L. (2001). Reading Activities for Effective Top-Down Processing. Forum, 39(1), 22.

[12] Charlotte, S. H and Barbara, Z. K. (2004). Children's Literature in the elementary school (New york; Mcgraw-Hill, 2004), P 12

[13] Danan, M. (1992). Reversed Subtitling and Dual Coding Theory: New Directions for Foreign Language Instruction. Language Learning, 42, 497-527.

[14] Dempsey, D. J. (2009). Legally Speaking: 40 Powerful Presentation Principles Lawyers Need to Know. Published by Kaplan Publishing.

[15] Do, H.T.L. (2010). The Effects of Using Visual Aids on Teaching English Vocabulary at Thor Not High School. Master thesis. University of Can Tho.

[16] Dolati, R. \& Richards, C. (2011). Harnessing the Use of Visual Learning Aids in the English Language Classroom. Arab World English Journal, (21), 3-7.

[17] Dolati, R. \& Richards, C. (2012). The Perception of English Language Teachers in the Use of Visual Learning Aids. Journal of Applied Sciences Research, 8 (5), 2581. 2595

[18] Domin, E. A. (2007). On Application of Visuals in Teaching English; selected issues. 


\section{DOI: $\underline{10.51386 / 25815946 / i j s m s-v 4 i 5 p 123}$}

Volume: 4 Issue: 5

September to October 2021

https://www.ijsmsjournal.org

[19] Erten, I. H. \& Razi, S. (2003). An Experimental Investigation into The Impact of Cultual Schemata on Reading Comprehension. Paper presented at 2nd International Balkan ELT Conference, 20-22 June 2003, Trakya University, Edirne, Turkey.

[20] Grabe, W. (2009). Reading in a Second Language: Moving from Theory to Practice. Cambridge University Press. ISBN 978-0-52172974-1. Archived from the original on 2018-05-04. Koda, 2005:4

[21] Harmer, J. (2007). How To Teach English. England: Longman Pearson.

[22] Hill, D. A. (1990). Visual Impact. Creative Language Learning through Pictures. England: Longman Group UK Limited.

[23] Hoban, C. F., \& Ormer, E. B. (1970). Instructional Film Research 1918-1950. Ayer Publishing.

[24] Izza, M. Rz (2016). The Effectiveness of Using Pictures in Teaching Vocabulary. Walisongo State Islamic University.

[25] Jin, N., Chen, Z., \& Wang, J. (2019, September). Designing a Mobile-Assisted English Reading Class for College Students. In International Conference on Web-Based Learning (pp. 332-338). Springer, Cham.

[26] Jordan, R. R (1997). English for Academic Purposes: A Guide and Resource Book for Teachers. Cambridge: Cambridge University Press

[27] Lipton, L. E., \& Wellman, B. (1998). Pathways to understanding: Patterns and practices in the learning focused classroom (3rd ed.). Sherman, CT: MiraVia.

[28] Miller, D. L. (2011). Visual Approaches to Vocabulary Instruction: Teacher and Adolescent Learner Perceptions. Doctor's thesis. India University of Pennsylvania.

[29] Nafean.T \& Miftahul.R (2012). Reading Basic Reading Skill 1. (Serang: Loquen Press, 2012) p.6

[30] Nguyen, T.M.N \& Do, M. H. (2021). EFL Teachers' Evaluation and Adaptation of the Reading Lessons in the Piloted Tieng Anh 12. International Journal of Science and Management Studies (IJSMS), v4(i4), 325-338.

[31] Nguyen, B. N et al. (2021). Investigating Difficulties of Self-Study in Reading Skills of English Language Students of the HighQuality Training Program at Can Tho University. International Journal of Science and Management Studies (IJSMS), v4(i5), 72-80.

[32] Nguyen, T. N. H \& Nguyen, H. Q. (2021). High School Teachers' Perceptions of the Intercultural Communicative Language Teaching (ICLT) Model Applied in Language Classrooms- A Case Study of a Vietnamese High School. International Journal of Science and Management Studies (IJSMS), v4(i5), 27-46.

[33] Osei, A. M., Liang, Q. J., Natalia, I., \& Stephen, M. A. (2016). The use of Pre-Reading activities in reading skills achievement in preschool education. European Journal of Educational Research, 5(1), 35-42.

[34] Oyarzo, A. S. P, Vargas, M. A. P., \& Reyes, J. E. R. (2008). Realia and Vocabulary Learning among Young Learners. Chile: University of Chile

[35] Palacios, T, Guzmán, Z., Ortiz, L. (2021). The Use of Pictures As Visual Aids to Increase Reading Comprehension. Universidad Nacional Autónoma de Nicaragua UNAN- MANAGU

[36] Pan, Y. C (2009). The effects of pictures on the reading comprehension of low-proficiency Taiwanese English foreign language college students: An action research study. National Pingtung Institute of commerce, Taiwan

[37] Paul, X. J, \& Christopher, G. (2017). Teaching Reading Skill Using Heuristic Technique Through Schema Theory. IUP Journal of English Studies, 12(1), 11

[38] Porter, J. (2012). Methodological Issues in Collecting Children's View's Part 2: Using Nominal Group Technique to Explore Children's Views of The Difficulties Encountered in School. University of Bath, England.

[39] Purwoningsih, D. (2007). Using Visual Dictionary in Teaching Vocabulary to Elementary School Students. State University of Semarang

[40] Richards, J.C. (1998). Beyond Training. Cambridge: Cambridge University Press

[41] Sadiman, A. S. (2007). Media Pendidikan: Pengertian, Pengembangan, dan Pemanfaatan. Jakarta: PT. Raja Grafindo Persada

[42] Shabiralyani, G., Hasan, K. S., Hamad, N., \& Iqbal, N. (2015). Impact of Visual Aids in Enhancing the Learning Process Case Research: District Dera Ghazi Khan. Journal of Education and Practice, 6(19), 226-233.

[43] Suciati, G. D (2009). Analysis On Advantage and Disadvantage of Teaching the Present Continuous Tense Through Pictures Even Semester of Eight Grade Students at SMPN 2 Pamulang. Universitas Islam Negri 
DOI: $\underline{10.51386 / 25815946 / \mathrm{ijsms}-\mathrm{v} 4 \mathrm{i} 5 \mathrm{p} 123}$

Volume: 4 Issue: 5

September to October 2021

https://www.ijsmsjournal.org

[44] Thuraisingam, G., Gopal, S., Sasidharan, N., Naimie, Z., \& Asmawi, A. (2017). Implementing Pre-Reading Strategies to Improve Struggling ESL Learners' Interest and Comprehension in English Reading Lessons. Int. J. Edu., Culture Soc., 2(3), 94-100.

[45] Tran, T.T.T., \& Phuong, Y.H (2018). The Impact of Questioning and Semantic Map in Pre-Reading Stage on Students' Reading Comprehension: A Comparative Study. European Journal of Education Studies, 4(6), 279-294.

[46] Wilen, W.W., \& Clegg, A.A (1986). Effective Question and Questioning: A Research Review. Theory and research in social education

[47] Wright, A. (1989). Pictures for Language Learning. Cambridge: Cambridge University Press.

[48] Umatsu, H. (2012). The use of pictures and illustration in teaching English. $21^{\text {st }}$ Century. Education Forum, Vol.7. 